\title{
Materialistic and Spiritual Issues in Flannery O'Connor's Wise Blood: An Analysis
}

\author{
Preeti Singh ${ }^{1}$ and Mahesh Kumar Arora ${ }^{2}$ \\ ${ }^{1}$ (Department of Management and Humanities/Sant Longowal Institute of Engineering and Technology, India) \\ 2 (Department of Management and Humanities/Sant Longowal Institute of Engineering and Technology, India)
}

\begin{abstract}
This paper presents the way in which Flannery O'Connor, who was tagged as one of the most important Southern female writers in the post-war America, succeeded in depicting a world full of contrast, by showing how the materialism of modern society shows the major themes of redemption and the grotesque. Wise Blood is Flannery O'Conner's first novel and since its publication, it has always been regarded as a difficult work to understand because of its religious themes, darkness, absurd plot, gothic horror and grotesque characters such as repulsive, wicked and unredeemable. In this novel she puts stress on massacre, insanity, estrangement and redemption. As a writer overflowing with a very strong sense of social responsibility and Catholic Beliefs, O'Connor dares to disclose the vices and virtues or sins and evils, and ways of salvation of the modern people. This work also examines the implication of human existence from a Christian point of view, philosophical themes and commercialized world overflowing with social corruption, spiritual blindness and moral decline.
\end{abstract}

Keywords- Grotesque, materialism, modern prosperity, modern world and spirituality.

\section{Introduction}

The American writers perceived the vast potential of the grotesque genre to reach the sublime by mixing of disaster and humor, the absurd and the terrible. Wise Blood communally and religiously reflects O'Connor's immense concerns for humankind. After the World War many Americans enjoyed financial prosperity at a grand level. The development in modern advertising industries and marketing technologies created extensive economic enlargement. Americans became enthusiastic consumers, spending money to buy new products brought by technology. But with this material prosperity America faced negative aspects too. The people of America became greedy and materialistic. This technological world and its dehumanizing consequences changed the level of relationships, values of love, honesty, parity, and loyalty. Devastating pursuit of wealth caused people to have little time to cultivate their spiritual world. The American dream of innocence and material wealth, the world wars, and the outburst of principles and values landed up the people in the depths of misery. Crisis of faith followed material richness. The sense of meaninglessness in life, isolation, duplicity, anxiety and lack of spirituality forged a tragi-comic vision of life. Afterwards, the loss of the civil war diminished agricultural system leading to economic poverty, abnormality and lack of sufficient code for living filled the people with a feeling of dislocation and ennui. The war shaped a deeper predicament of faith in the communal consciousness of the Americans. As a result the writers often embraced the grotesque mode in their works to understand the nature of modern man and his split self. An extensive part of the American grotesque writing is the deep contribution of the south. William Faulkner, Robert Penn Warren, Carson McCullers, Erskine Caldwell, Flannery O'Connor, Eudora Welty, Truman Capote and Walker Percy are the most important southern masters of the grotesque. Hence the writers fictionalized the bad condition of modern man who didn't belong to the human race at all in grotesque terms.

Flannery O'Connor has been recognized as one of the most gifted and provocative writers of the American South. She has been acclaimed both as a short story writer and as a novelist. Her critics are sometimes uncertain about what group; she may be placed in, whether she could be best understood as a religious writer, a Southern writer or an artist who specializes in the use of violence and grotesque. V.S. Pritchett observes in his introduction to Wise Blood that her originality springs from her peculiar situation as a member of an Old Catholic family established in Georgia and surrounded by poor whites and Protestant sectarians of the Bible belt. She is a religious writer but she is not didactic in tone nor is she concerned with conflicts of doctrine. She finds people are misled and misguided by the itinerant and ignorant preachers and so she attempts to evoke the disordered images in the minds of the pervading sects with the sharpness of an anthropologist. She simply relates what she sees and hears to older experience (Pritchett, 1996: vii). Indeed, the very presence of modernity creates new forms and values by transforming and destroying old ones. According to Di Renzo, "the grotesque world is constantly in flux with no correlation between the interior state and the external appearance, thus creating a radical disjunction between how one is, how one perceives one's self to be, and how one is perceived 
by others" (Renzo, 1993: 151). Such a state exists within the south, especially during the modern and postmodern eras, and O'Connor draws upon that fact to craft her grotesques.

Flannery O'Connor chooses grotesque as her literary genre for the specific purpose of making people understand her correctly. Keller observes that "As an orthodox and ardent Roman Catholic, she viewed the essentially godless condition of modern times as anathema and the secular society as doomed to depravity by its own wrongheaded refusal to recognize the truth of God and to follow God's commandments. She was particularly critical of the secular notion that men can define moral absolutes for themselves. Man's reliance upon reason to define such absolutes as goodness and comparison leads only to Auschwitz, she believed, for reason in men is by definition corrupt and can only be depended upon to lead to self-deception. Secular humanism, for all its professed unselfish idealism, leads not to the love that it posits as its goal but to the suicide of a whole civilization. Some of Miss O'Connor's best writing blazes with the force of her wish to make society look at the reality that it tries to ignore and to destroy men's illusions and pretenses about themselves and their times by exposing the naked truth. Such a realistic confrontation with the truth is all that can save the world in Flannery O'Connor's view, and to this end she wished to persuade her readers to share her critical attitude" (Keller, 1972: 263-73). She evokes to meaningless empty world, which she saw as the condition of the modern world cut off from its roots in the holy, in being. O'Connor through her exploration of distortions and the evil of the social reality she wants to awaken the people from their immoral lives, because she sees them under the light of eternity, and is deeply concerned with the spiritual deprivations which they suffer because of their unsatisfied hunger for God.

Her work is full of humor and deep consciousness of grotesque; macabre death, eccentric characters, bizarre situations and violent behaviors. According to Doll, she observes, "Fiction is not only necessary for pedagogy; fiction is the lie that pedagogy needs in order to uncover the truths that make us human" (Doll, 2000: xii). Through the lenses of Biblical vision O'Connor's instructive work exposes darker truths of humanity. O'Connor conveys "the horror of responsibility, judgment, and the burden of morality, all presupposing a set of values that transcend the individual and dignify him by their demands" (Martin, 1968: 160), her grotesque assumes the dual responsibility of offering criticism if her characters not succeed. She does not want to say that neither south was or is perfect nor the present is superior to the past. What she does is use the grotesque to signify the character's inability or unwillingness, and most importantly her clear-eyed belief in Christian faith. Her depiction of the grotesque is unique because her explanations and usages are tied to her firm sense of spiritual realities that southern writers, have always been more ready to acknowledge than other American are. Flannery O'Connor is a superb artist of the grotesque who manipulates her lurid tales to create moments of grace in an absurd and topsy-turvy world of sin, distortion and reconciliation. Her imagined South is defined as that Christ-Haunted which characters can be forgiven anything except spiritual complacency. So we can say that the grotesque is actually the realization of the enlargement of spiritual emptiness and distortions, which was veiled by social aggression and bizarre actions.

\section{Grotesque in Wise Blood}

Flannery O'Connor's very first novel Wise Blood is centered on the theme of redemption. It is the story of Hazel Motes who tries desperately and violently to defy his fundamentalist background but who finally accepts the harsh reality of sin, redemption and experience of Christian salvation. Hazel Motes who has a grotesque profile, driven by the old ambition of becoming a prophet, buys an Essex, and moves about the city of Taulkinham preaching a new church "the Church of truth without Jesus Christ Crucified" (O'Connor, 1949: 105), but he cannot avoid the visitation of grace upon him and then blinds himself to prove his belief in Christ. His moral depravity prods him to declare that he has no need of Jesus.

In Wise Blood, both Hazel and his city are deprived from their morality. Here, the emphasized morally blind boundaries of the urban setting (city) also define a world in which the spiritual has no place, as a world in which everything is for sale. Early in the novel the readers find the city of Taulkinham filled with a very strong sense of commerce as soon as Hazel Motes steps off the train. He sees electrified "signs and lights" advertisements of "PEANUTS, WESTERN UNION, AJAX, TAXI, HOTEL, CANDY", (O'Connor, 1949: 29) they were moving up and down everywhere or blinking frantically. The Taulkinham policeman ridicules Hazelthe-country-boy for not knowing about spotlights. People entering and leaving the shops, sellers pitching their voices and the scenes of debauchery make Hazel Motes nervous and dizzy. But it contrasts with the reality; this orgiastic religion is the tradition of the region. "The stores in Taulkinham stayed open on Thursday nights so that people could have an extra opportunity to see what was for sale" (O'Connor, 1949: 37). They adopt the tone of the high-pressure salesman and offer the people bargain. This superficial material prosperity is the moral degradation and spiritual blindness. The walls of Men's Toilet are "decorated with handwriting and with various detailed drawings of the parts of the body of both men and women" (O'Connor, 1949: 30). The walls are also used as an advertising board for prostitutes to issue messages about selling sex. In the starting of chapter five we find the description of "heart of the city", the park, which has a swimming pool, a zoo, and a small forest. The 
city has a museum and a theatre also- all represents the images of imprisonment and leisure given by the prosperous society. It is the moral wasteland for the modern man who engages in the material world, a world which is spiritually empty, morally blind, cold and hostile.

The anxieties of the people in the world of Wise Blood are things and materials rather than spiritual. Flannery O'Connor's world is full of characters, which are dwelling in rural locales, they have occupations and families, but they are fallen creatures and deprived of the mercy of God attributable to their own will. They have powerless perfection, but still they act as to be the part of modern attraction to secular humanism. As a sense of this modern consciousness developed in 1950's America, the role of farmers, industrialists and the bosses of other fields changed. With this uncertainty- the confused, alienated and faithless modern man's life becomes circumscribed by the material world is as seen in figures like- Hazel Motes, Asa Hawks and his daughter Sabbath Lily Hawks, Enoch Emery, Hoover Shoats and Mrs. Flood. They only think that they can save themselves by replacing spiritual values with material values, but they remain spiritual grotesque. Even a leanfaced potato-peeler salesman is a kind of priest of money. He wore a "small canvas hat and a shirt patterned with bunches of upside-down pheasants and quail and bronze turkey" He was pitching in high voice so that everyone can hear. He draws a crowd and offers his "bargain" to them. His pyramid of "green cardboard boxes and, on top of the stack, one peeler were open for demonstration" and behind the "altar" (O'Connor, 1949: 38) of the machines he sells his dreams to be a rich man. O'Connor's characters obviously resort to an anti-Christ stance in the beginning in a relative way, but in the end, they surrender to Christ unquestioningly and ungrudging and affirm their faith in redemption.

The story starts with the principal character, Hazel Motes, who is a modern saint, who isolates himself from God and doesn't believe in society's norm and the law. He is not so much a human being as a grotesque parody of humanity. He is comically pathetic run away from God, trapped by his fate. Gradually the story is changed from farce, what he actually pretends in the story, to a serious study of the problem of redemption in the modern world. While wandering in Taulkinham to preach his gospel of "Church without Christ" (O'Connor, 1949: 105), he comes into contact with the sordid characters that comprise this modern world: among them, two fake preachers Shoats and Asa Hawks; a preacher whose simulated blindness becomes for Hazel a temptation and a challenge, his unholy daughter, Sabbath Lily; whose body cries for Hazel's and a false disciple Enoch Emery. They all, initially take an interest in him because according to them, he can bring money and make them rich. Hazel also thinks that material prosperity is the basic platform where he can establish his Church without Christ. The major symbol here is the automobile, the symbol of modernity and prosperous world. The Hazel's car is an old Essex. The car "was a high rat-colored machine with large thin wheels and bulging headlights" and "one door was tied on with a rope" (O'Connor, 1949: 69). It becomes Hazel's pulpit where he climbs up and preaches his Church without Christ. Hazel's awakening starts when a patrolman calls him to drive his car to the top of the next hill and pushes the car over the hill and destroys it. Hazel looks over at the scene. Staring into the "entire distance that extended from his eyes to the blank grey sky that went on, depth after depth, into space," this place is never noticed by the people walking beneath it. Hazel sees it is his recognition and appreciation of the depth before him that finally allows him to end his quest for some other place. It is also immediately after this revelation that he decides to commit the grotesque action of blinding his eyes with quicklime. Hazel stares into the distance, his illusion of freedom destroyed; he is forced to consider a reality other than the material world. Readers experience Hazel Mote's grotesque conversion through his penances such as wearing shoes which are "lined with gravel and broken glass and pieces of small stone" (O'Connor, 1949: 221) and having "three strands of barbed wire, wrapped around his chest" (O'Connor, 1949: 224). The moral anguish of Hazel Motes is caused by the spiritual poverty he finds in the modern city.

Perhaps the best indication of economically corrupt character is found in Mrs. Flood, Hazel's landlady; at once, the greediest person in the novel and the nearby thing of an ordinary citizen of Taulkinham. She plans to take advantage of Hazel's pathetic Blindness. She raises the rent for putting up with the way his thin face looks, raises his rent for letting Sabbath Lily stay with him, and raises his rent when she finds out how much he earns from the government. She plans to marry him in order to get control of his government pension. It is true that Hazel's act of self-mutilation does have a positive effect on the selfish and self-centered Mrs. Flood. Initially, she feels cheated financially, but when Hazel dies she thinks that he may have known something she did not. The story creates a grotesque effect on the readers when Mrs. Flood, converses with the Corpse of Hazel Motes, taking him to be alive: "I knew you'd come back," she said. "And I've been waiting for you. And you needn't to pay any more rent but have it free here, any way you like, upstairs or down. Just however you want it and with me to wait on you, or if you want to go on somewhere, we'll both go" (O'Connor, 1949: 231). In Wise Blood all characters think themselves as Christian or good people, but their actions and attitudes reveal otherwise. Their arrogance blinds them to their own fault, and through the revelation by other sources they open their eyes and get a chance of redemption

The other chief character is Enoch Emery, who works at the zoo as a guard and is obsessed with the preserved old corpse in the town museum. He tells Hazel that he has been in Taulkinham only two months and 
that he already works for the city and buries himself in the rigidity of a daily routine. Enoch hopes to become a new man; he anticipates a new and improved self, but the ape suit only leads to a loss of identity. Enoch recognizes Gonga the gorilla, as a symbol of success in the modern world. But instead of working towards that goal, Enoch disappears himself into the gorilla suit. Because this adopted change is superficial. Enoch's pathetic transformation is representative of the people's tendency to address a trouble by changing its look. Enoch's plan eventually fails, and he is very last seen alone and unaffected. Another character is Hoover Shoats, for instance, he uses religion for commercial profit. He is attracted to Hazel's idea of a new Jesus and wants to form a business partnership with him, but not for any spiritual and pious reasons, but because it is a beneficial opportunity that simply needs a few endorsements. Hazel rejects the partnership, Shoats hires Solace Layfield, who looks like Hazel and has a car like Hazel. Thus, Miss O'Connor again reveals the distorted sense of spiritual purpose in the form of commercialized religion.

One more example of spiritual depravity and embrace of the material world is Asa Hawks. Asa Hawks, a preacher and with whom Hazel is obsessed, is more complex. He fails in his attempt to blind himself with quicklime "to justify his belief that Christ had redeemed him" (O’Connor, 1949: 112). From that day, however, Asa has acted the part of the blind preacher, using the trick of his handicap to attract crowds to gain sympathy in begging and bamboozle them. When Hazel meets him, he is making money by preaching and, more significantly, by not preaching, he does just what his name implies- he hawks his religious merchandise in the streets: "Help a blind preacher. If you won't repent, give up a nickel. I can use it as good as you. Help a blind unemployed preacher. Wouldn't you rather have me beg than preach? Come on and give me a nickel if you won't repent" (O'Connor, 1949: 40). Here obviously is a man whose sense of spiritual purpose is distorted. Sabbath Lily Hawks, Asa Hawks's fifteen-year-old daughter, helps her father by handing out pamphlets. Without any hesitation she openly acknowledges that she is not responsible for her parents' sins; she being born a bastard doesn't mean she is not qualified for the mercy and salvation of God. We find another religious ignorance when she reveals that she wrote a letter to a newspaper advice columnist, Mary Brittle and justifies her lifestyle with her intellect, seeking guidance on her love life: "Dear Mary, I am a bastard and a bastard shall not enter the kingdom of heaven as we all know, but I have this personality that makes boys follow me. Do you think I should neck or not? I shall not enter the kingdom of heaven anyway so I don't see what difference it makes" (O'Connor, 1949: 119). Mary replies: 'Dear Sabbath, Light necking is acceptable, but I think your real problem is one of adjustment to the modern world. Perhaps you ought to re-examine your religious values to see if they meet your needs in Life. A religious experience can be a beautiful addition to living if you put it in the proper perspective and do not let it warf you. Read some books on Ethical Culture." (O'Connor, 1949: 119) As she was not satisfied with the response she again replies: "Dear Mary, What I really want to know is should I go the whole hog or not? That's my real problem. I'm adjusted okay to the modern world" (O'Connor, 1949: 120) Through Sabbath, it is clear that how people rudely discard God and act honorably according to their own free will in the fictional world of Miss O'Connor. Sabbath Lily may seem at first to be driven by lust, but ultimately it is an economic necessity that drives her. The sarcastic reality is that she is totally adjusted in O'Connor's Wise Blood and acceptable to the modern world.

The pressure of the modernism and industrialism gives shape to the physical and mental distortion that is the best representation of the grotesque. When God reaches out to touch the lives of the fake modern men, he doesn't understand the mercy and reject the revelation offered. O'Connor says that it is better to come to a position of humanity when man's final concern with himself is that of intellectual pride in material possessions, and this love of possessions entangles man's determination and he fails to recognize the surprise that the God sends him particularly when religious and spiritual ethics are distorted for material gain as in the case of both the fake preachers Hawks and Shoats.

\section{Conclusion}

This study has shown the work of Flannery O'Connor, which represents the grotesque and how the grotesque has become the result of her character's association with the modernity. The modernity has taken the characters far from the reality, beliefs and their faith. O'Connor's grotesque characters are taken from southern people who most do not believe in God. They have lost their faith in God. Through her pious work she wishes that her readers could believe that God does exist as she once said "my audiences are the people who think God is dead. At least these are the people I am conscious of writing for" (O'Connor, 1972: 80).

In Wise Blood, people are depicted as trapped in the world, deprived of spiritual and moral nourishment to seem very superficial, inhuman and distorted. According to Josephine Hendin, "Two worlds coexist in Wise Blood: one is world of mechanical "becoming," a world that is like an elaborate erector set; the other is a world in decline and decay not unlike an open grave" (Hendin, 1970: 47). In such a world, where life has no meaning, society is brutal and evils are widespread, a place without the corrupting nature of the modern society and human sin and evil cannot be imagined. Throughout the novel is an emphasis on money and modern culture. From the very first page of the novel, we find Mrs. Wally Bee Hitchcock on the train squinting to see the price 
tag on Hazel's suit; Emery acquires a gorilla costume to maintain the identity of an ape in exchange for money and attention, Leora Watts and Sabbath Lily Hawks prostitute their bodies.

Father, Asa Hawks and daughter, Sabbath work together for the same goal but acts are different to achieve it, Asa blinds himself for begging and Sabbath seduces Hazel Motes for his money. The street vendors and the used-car salesmen haggle over prices, electrified advertisements blinking frantically on the roadsides and there is much more detail that supports the motifs and imagery of material prosperity but this superficial material prosperity is the moral degradation and spiritual blindness. In sum, through these distorted senses of moral purpose in the characters, redemption is difficult. Only one is redeemed in the last of the novel and the rest move aimlessly in ethical and spiritual anarchy, they stay grotesque, downright, absurd and cruel.

\section{References}

[1] V.S. Pritchett, "Introduction". Wise Blood (London: Faber and Faber, 1996).

[2] A. D. Renzo, American Gargoyles: Flannery O'Connor and the Medieval Grotesque. (U.S.A.: Southern Illinois University Press, 1993).

[3] J.C. Keller, The Figures of the Empiricist and the Rationalist in the Fiction of Flannery O'Connor. Arizona Quarterly, Autumn,1972,263-73.

[4] M.A. Doll, Like Letters in Running Water: A Mythopoetics of Curriculum (Mahwah, NJ: Lawrence Erlbaum Inc., 2000).

[5] C.W. Martin, The True Country: Themes in the Fiction of Flannery O'Connor (Kingsport, TN: Vanderbilt United Press, 1968)

[6] F. O’Connor, Wise Blood (New York: Farrar, Strauss and Giroux, 1949).

[7] F. O'Connor, Mystery and Manners (London and Boston: Faber and Faber Limited, 1972).

[8] J. Hendin, The World of Flannery O'Connor (Bloomington/London: Indiana University Press, 1970). 